\title{
restorative justice in the pacific islands
}

\author{
an introduction
}

\author{
Sinclair Dinnen \\ Department of Political and Social Change \\ Research School of Pacific and Asian Studies \\ Australian National University
}

\section{About the Conference}

Most of the chapters in this book were presented as papers at a three-day conference in Port Vila, Vanuatu, in June 2000. Organised jointly by the Australian National University's State, Society and Governance in Melanesia (SSGM) Project and the Law School of the University of the South Pacific (USP), the conference was held at the Emalus Campus of USP. 'Restorative Justice and Conflict Management in the Pacific Islands' provided the broad theme for discussion of different approaches to crime and conflict in the Pacific Islands and, in particular, in the Melanesian countries that provide the research focus of the SSGM project. In addition to the operations of formal state mechanisms, speakers were encouraged to address informal approaches to conflict resolution including quasi-traditional strategies and the role of non-state agencies. There are growing concerns about conflict and criminality in many parts of the Pacific Islands. 'Law and order' problems, as they are euphemistically termed, reflect the many dislocative effects of larger processes of social and economic change taking place in the region. Much of the policy debate generated by these developments has been directed at the need to strengthen state agencies and processes of law enforcement. Less attention has been paid to the role, actual and potential, of those informal 
structures and processes that in many places continue to wield more influence than do the institutions of the modern nationstate.

In addition to general issues of lawlessness, the region has been shaken by a number of complex internal conflicts in recent years. These have inevitably focused attention on the challenges of conflict prevention and resolution. A nine-year civil war on Bougainville, precipitated by landowner grievances over levels of compensation for mining development, has inflicted enormous suffering on the people of that island, as well as causing significant economic and political damage to Papua New Guinea. In May 2000, just over a month before the Vanuatu conference, George Speight led an armed takeover of the Parliamentary complex in Suva and held Prime Minister Mahendra Chaudhry and members of his Cabinet hostage. As with the earlier Rabuka-led coup of 1987, the Speight coup was executed on the pretext of protecting the rights of indigenous Fijians against alleged encroachment by Indo-Fijians, particularly in relation to land. These actions have had devastating social, economic and politics impacts in Fiji.

On the 5th June 2000, a couple of weeks after the Fiji coup, members of an armed militia group (the Malaitan Eagle Force - MEF), with the active collaboration of elements of the Solomon Islands police, seized control of key installations in the national capital, Honiara. Prime Minister Bartholomew Ulufa'alu was forced to resign. The Solomon Islands coup had been preceded by two years of mounting tensions between the indigenous inhabitants of Guadalcanal and settlers from the neighbouring island of Malaita. Up to 20,000 of the latter were displaced forcibly from their rural homes by militant Guadalcanal groups. These events paralysed the Solomon Islands state and national economy and resulted in the collapse of the national police force.

The issue of violence in Melanesia was the theme of a previous SSGM conference. ${ }^{1}$ As well as highlighting the diverse impacts of violence, several speakers at that conference talked about interesting informal approaches to conflict resolution. These entailed adaptations of older traditions of dispute resolution and their combination with aspects of the modern state 
system. Such innovative responses were often a response to the perceived failings of both existing state and non-state solutions to conflict and infraction. While some of these have occurred in the realm of criminality, as in the case of gang surrenders in Papua New Guinea, ${ }^{2}$ others have arisen in the context of larger conflicts. The Bougainville peace process, in particular, has given rise to many interesting approaches to conflict resolution and reconciliation between former adversaries. ${ }^{3}$

The Vanuatu conference presented a timely opportunity to explore a range of different responses to conflict in the contemporary Pacific. While some of these are centred on state agencies, others entail partnerships between state and non-state entities, while yet others involve no participation by the state at all. Approaches with little or no state involvement tend to be the least known, usually occurring in rural areas far from the view of urban-based policy makers, media and donors. Speakers were invited from Vanuatu, Fiji, the Solomon Islands, Papua New Guinea (including Bougainville) and Australia. They included academic researchers, senior representatives of the formal law and justice sector, policy makers, community leaders, and members of non-government organisations and churches. Each shared a personal or professional interest (often both) in reducing and resolving conflict in a variety of social and institutional contexts. The resulting volume reflects the diversity and richness of their views and experiences. The assessments offered are tentative rather than conclusive and, inevitably, the enthusiasm of some speakers was tempered by the reservations expressed by others. It is clear that there is no single restorative justice approach and that restorative strategies can be adapted to particular circumstances. Indeed, it is this capacity to adapt to different cultural and institutional contexts that enhances the appeal of restorative justice in the socially diverse Melanesian environment. Our main objective in publishing this volume is to bring some of the more innovative and lesser known approaches to conflict to the attention of a wider audience. This, in turn, should contribute to policy debates on issues of great importance to the peoples and governments of the region.

The concept of restorative justice is a useful vehicle for stimulating thinking about the relationship between formal and 
informal justice practices and for exploring the desirability and practicality of developing more deliberate linkages between them. Restorative justice has emerged as a significant reform movement in many Western countries in recent years. It has been most influential on juvenile justice but has also had a growing impact in debates about other forms of conflict and dispute resolution. Restorative justice is often conceived as a process that brings together all the stakeholders that have been affected by a particular harm to discuss the effects of that harm and how they might best be remedied. ${ }^{4}$ It is an inclusive and participatory approach to dispute settlement, in contrast to the exclusionary character of formal court proceedings under state justice. Restorative justice also emphasises the need to heal the damage caused by conflict or infraction. While the term 'restorative justice' was new to many of those at the Vanuatu conference, there was no difficulty in recognising its similarities with older approaches to dispute resolution still practised in many Pacific communities. It was this resonance between restorative justice and more 'traditional' approaches that aroused most interest and opened up lively discussion about the need to develop more socially attuned strategies for meeting the challenge of new forms and levels of conflict.

\section{Law, Order and the State}

Contrary to a 'common sense' view of conflict as inherently pathological, history teaches that it is a normal feature of all human societies. Our personal experiences attest to the regularity of disputes in everyday life, whether in the context of our families, relationships, communities, recreational activities or workplaces. While a certain level of disputation is to be anticipated, endemic conflict undermines the cohesion and stability of society and, if left unchecked, can threaten its continued existence. Some degree of order and regularity is necessary to sustain social life in any community. Every society has devised ways of dealing with conflict, disputes and infractions of agreed norms. These have reflected the prevailing social and political values and the organisation of the society in question. For the classical philosophers of the European 
Enlightenment, restraints on individual freedoms and the creation of a dominant authority were deemed necessary in order to avoid a condition of perpetual conflict. The unpalatable alternative was depicted most vividly in Thomas Hobbes's famous dictum about life in a state of nature. In the absence of a 'common power' or authority to enforce rules and restrain individual behaviour, Hobbes foresaw a situation of 'warre of every one against every one' where life would be 'solitary, poore, nasty, brutish and short'. ${ }^{5}$

An enduring legacy of this school of political philosophy is the central role attributed to the modern state in the maintenance of peace and order within its territorial borders. Indeed, the capacity to maintain domestic order and provide protection against external threats continues to provide the basis of most standard definitions of the state. According to these, coercive powers are concentrated in the state in order to ensure order in the society at large. This is not just an issue about the distribution of coercive powers within a given polity: it also implies popular acceptance of the right of the state to use them under certain circumstances. In Weberian terms, the state is said to exercise a monopoly over the legitimate use of violence. ${ }^{6}$ Violence emanating from non-state sources that is not sanctioned by state authority is by implication illegitimate. To fulfil its role, the modern state has established an elaborate coercive and juridical apparatus dedicated to the task of maintaining peace, security and order. In addition to military forces for defence against external threats, the maintenance of domestic order is provided for through a highly structured law and justice system comprising laws, police, courts and prisons. This system is represented as separate from other domains of state activity such as politics, and this differentiation is enshrined in the well-known constitutional doctrine of the separation of powers.

Criminal laws define and proscribe certain behaviour and provide for the punishment of convicted offenders. While there may be subsidiary aims such as the rehabilitation of offenders, the principal rationale of state-sanctioned punishments is deterrence. Infractions of the criminal law are dealt with as offences against the state with the prosecution of 
alleged offenders being conducted in the name of the state. The immediate victims are largely passive bystanders in this process. In the Western tradition, laws are enacted, enforced and interpreted by separate institutions, each staffed by personnel dedicated to particular aspects of the law and justice process. They are impersonal and universal in scope, applying, in theory at any rate, to every individual irrespective of his or her personal or official status. Criminal law has a 'public' quality. Suspected offenders are prosecuted by the state and, if found guilty, will be punished irrespective of whether any member of society claims to have been wronged or not. Given its concern with relationships between the state and individuals, criminal law is classified as a form of 'public' law. 'Private' law, on the other hand, concerns itself more with the regulation of relationships between individuals.

The Weberian depiction of states exercising a monopoly over the legitimate use of violence is, of course, an ideal type and in practice there are many modern states that patently lack the capacity to enforce this monopoly. Recent years have also seen a growing ideological critique of the centrality of the state associated with broader international transformations, including the liberalisation of trade, mobility of capital, migration, and growth of supra-national bodies. Weber's idealised construct is best understood in light of the distinctive historical processes of state formation that occurred among the proto-national states of Europe. These processes entailed a lengthy, and often turbulent, struggle to wrest power away from numerous relatively autonomous local and regional groups and rival institutions, and the gradual accumulation and concentration of this power in a unitary and centralised state for purposes of territorial domination. ${ }^{7}$ In today's era of privatisation and globalisation, the monopoly over coercive powers of even the strongest states has been diluted as a result of rising levels of private sector involvement in areas previously dominated by the state. This is evident in, among other things, the massive growth of private policing and security, including the provision of private military services. ${ }^{8}$

While strong states may have relinquished or otherwise delegated selected coercive powers, many weak states continue to struggle to assert their authority. Some of the latter never 
established control or domination of their designated territories in the first place. There are many reasons why some states are weaker than others. In post-colonial situations, this weakness is often a consequence of the short history of the state, its origins as a colonial imposition, and the manner of its articulation with pre-existing polities. While international thinking about states continues to be dominated by the very particular histories and experiences of a relatively small number of European states, processes of state creation and consolidation throughout much of the post-colonial world have followed a radically different pattern. ${ }^{9}$ In the Melanesian countries that provide the geographic and cultural focus of this book, the institutions of the nation-state were superimposed onto a patchwork of small-scale local polities, each with their own conceptions of sovereignty and traditions of self-regulation. ${ }^{10}$ There were no wars to resist colonial imposition or expel its agents that might have brought unity to the disparate Melanesian social environment. Nor have these polities disappeared under the cumulative weight of external change. On the contrary, they have proven to be remarkably resilient and adaptable. The difficulties experienced by the Melanesian states in asserting their territorial domination today derive, in large part, from the continued dispersal of authority and power within the 'national' society and the highly contested character of state authority. In the case of many 'citizens', primary identities and allegiances remain implanted in local languages and kin-based associations rather than in abstract concepts of 'nation' and 'citizenship'. Melanesia is famous for its high levels of social diversity and legal pluralism. These qualities make this region a fascinating field for the study of relations and interactions between different traditions of justice and dispute resolution. They also pose formidable practical challenges of how best to accommodate this diversity of local beliefs and practices within the unitary justice system of the modern nation-state.

\section{Order Without State}

The indigenous societies of the Pacific islands had ways of dealing with disputes and infractions long before the arrival of 
Europeans and the imposition of the first colonial states. These varied according to location, scale, leadership and authority structures, relationships to land, and the belief systems of different societies. The extent of this variation makes generalisation difficult but at the risk of over-simplification some broad observations can be made. Most societies were small and acephalous, lacking the centralized political and administrative structures associated with modern states. Power was diffused widely (at least among the adult men) rather than being concentrated in a single authority. There were no written laws in predominantly oral cultures or discrete systems of justice comprising institutions and bodies of specialists dedicated to the enforcement of rules and the adjudication of disputes. Rather than constituting a separate domain administered and enforced through discrete institutions and personnel, 'law' and 'justice' constituted an undifferentiated aspect of everyday social and political life. As Roberts puts it:

Despite the wide range of organizational forms which may be found in small-scale societies, the mechanisms for maintaining continuity and handling disputes tend to be almost universally directly embedded in everyday life, unsupported by a differentiated legal system. ${ }^{11}$

Whereas Western law treats the individual as a homogenous and isolated unit, a person's status, gender, kinship affiliations and relationships were integral to the determination of his or her rights and obligations in respect of others in Pacific Island societies. Disputes were defined and addressed within an elaborate complex of kinship, status and social relations. Women generally had a subordinate status to men, particularly in Melanesian societies. In the absence of centralized authority, there was no distinction between public and private spheres. Notions of reciprocity and equivalence were crucial to the redress of wrongs, as they were to other aspects of social and economic life. Such approaches typically entailed a strong element of bargaining and compromise, in contrast to the 'winor-lose' adjudication under Western common law. Resolutions of inter-group conflict were the outcome of protracted negotiations and were subject to re-negotiation when circumstances changed: 
Creating durable peace arrangements between clan groups were ongoing historical processes. The peace was not just made and left to happen. It had to be remade constantly by continuing exchanges. ${ }^{12}$

Inevitably any immediate settlement reflected the current distribution of power. The powerful interpreted kastom to their advantage and so when power changed so might kastom, and this increased pressure to renegotiate a previous settlement.

Given the high level of social inter-dependence in smallscale societies, the restoration of stable relationships ruptured by conflict or infraction was an important object of dispute settlement. Settlement processes were likely to involve protracted discussions and negotiations brokered or mediated by chiefs or other prominent local figures. In the case of larger disputes, settlements could take the form of ornate peace and reconciliation ceremonies involving the payment of compensation or the exchange of gifts. Compensation was a major component of peacemaking among groups. The main purpose of settlement in such cases was 'to re-establish a stable relationship between groups' ${ }^{13}$ Restorative resolutions were adopted in disputes involving parties bound together through kinship or other forms of social or economic association. Punitive or retributive approaches were more likely in the case of the most serious breaches of social norms or in situations where there was no morally binding relationship between the parties, as in the case of traditional enemies. Cycles of warfare and peacemaking characterised relationships between many groups. A lot of Melanesian groups have histories in which they attacked, killed or dispersed all the men, captured and kept some women, and occupied and retained the land of the former enemy. These asymmetrical encounters existed in group histories alongside relationships determined by long-term conceptions of balance.

\section{Colonial Interludes}

Set against the background of thousands of years of pre-contact history, less than a hundred years of colonial administration in Melanesia was a remarkably short period of time. While the 
advent of the colonial state was a portent of major social and economic transformations, it is little surprise that the precolonial past continues to pervade the post-colonial present. In the larger territories, the expansion of the administrative frontier was a gradual and uneven process hindered by lack of funds, inter-group warfare and the challenges of local topography. In many areas, it was the missions and plantations that had the most profound impact on Pacific islanders. As elsewhere, European colonization involved the arbitrary partitioning of territories with little concession to existing social and political groupings. Different external powers brought their own values, priorities, institutions and styles of administration.

The extent and nature of the recognition of local institutions and kastom by colonial authorities varied from territory to territory. In some cases, as in Fiji, deliberate attempts were made to adapt and co-opt elements of indigenous power structures - in the form of chiefs - into the maintenance of colonial order and pursuit of other instrumental ends. Elsewhere, including most of the Melanesian territories, colonial authorities found it more difficult to identify suitable local structures through which to work. There was perceived to be a lack of authoritative local leaders, and group identity and membership were uncertain and mutable. From the perspective of colonial authorities, there was no obvious local nexus of power. In the words of an early colonial judge in the Australian administered territory of Papua:

There being no semblance of a legal system to serve as a foundation, Government was not faced with the problem of choice, and the only hope for posterity was of the establishment of the legal system of civilisation to the exclusion of all else. ${ }^{14}$

Colonial rule entailed the introduction of selected Western laws and legal institutions. These included a combination of Western-style courts administering the introduced law, special courts or tribunals to administer 'native regulations' to indigenes, an armed constabulary and a rudimentary prison system. Reflecting the meagre resources available to most administrations and tenuous character of colonial authority, Western-style courts were largely confined to 
small expatriate enclaves. These Courts, staffed by professional magistrates or judges, dealt with the most serious offences and managed commercial disputes arising within the European community. 'Native Courts' dealt with disputes and offences involving indigenes as provided for under specially designated 'native regulations'. These relatively informal forums would also draw on the district or patrol officer's knowledge of local kastom, often as explained to him by an indigenous policeman or other official who might be from a different area. Colonial justice of this kind entailed the subordination of many of the formal attributes of legal justice to the administrative imperatives of the colonial project. Administrative officers often combined law jobs, serving simultaneously as magistrates, police, and jailers, in an undifferentiated system of 'native administration'. ${ }^{15}$ The principal aim was to establish a semblance of order and administrative control rather than to build an elaborate system of justice.

Western law had an extremely limited influence and most indigenous communities continued to deal with conflicts, disputes and infractions according to local kastom. Traditional structures were only interfered with when perceived as a threat to colonial authority or European prestige and continued to shape the daily existence of most Melanesians. Ironically, while official thinking maintained that indigenous institutions were inadequate to the task, in practice colonial administrations were dependent on them for the maintenance of peace, given the minimal reach of weak colonial states. Informal interactions between isolated district officials and indigenous groups were often conducive to dispute resolution at local levels. The former could draw on a range of agency powers extending well beyond official magisterial powers. Dispute resolution could thus be linked to the provision or withdrawal of various 'government' services allowing officers to persuade and reward, as well as to punish. Remedies could be addressed to either individuals or groups. European officials rarely spoke the local language and this increased their dependence on intermediaries. In a broad sense, the 'administrative justice' practised on the colonial frontiers accorded with indigenous practices because it approached dispute resolution in a more holistic way than was 
possible under formal western juridical practice. In doing so, it produced outcomes that were generally acceptable in local terms. There are continuities between this form of justice, particularly its holistic and problem solving approach, and many of the informal restorative justice practices that have sprung up in recent years.

\section{Post-independence Law and Order}

The establishment of the modern framework of Western justice commenced in earnest in the later stages of colonial administration. It involved the gradual repeal of discriminatory and paternalistic systems of 'native administration', replacement of the dualistic approach to dispute resolution with a unitary court system, and the separation of the administrative and judicial powers of the colonial state. Police forces that had been created originally as the key instrument for the extension and consolidation of colonial authority were to be transformed into professional and neutral law enforcement agencies. These changes were part of a larger project of institutional modernization aimed at transforming colonial institutions into those of the modern nation-state as a prelude to eventual independence and nationhood. When independence finally arrived in the 1970s, the Pacific island countries inherited the familiar institutional framework of the Western justice system with written laws, formal courts, police forces, and prisons. While this system was reasonably well entrenched and understood in some places, the transition was less straightforward in others.

This was particularly the case in Papua New Guinea, the Solomon Islands and Vanuatu. These countries shared a much higher degree of social and political fragmentation than Fiji and had a shorter and more uneven experience of centralized administration. Vanuatu (formerly the New Hebrides) had the additional legacy of being subject to two separate systems of colonial law under the administration of the British and French Condominium. In each case however, local systems of selfregulation or kastom continued to exert a more direct influence on the daily lives of their predominantly rural inhabitants than 
did the formal laws and institutions introduced by weak and under-resourced colonial regimes. Encounters between these different systems of justice inevitably gave rise to misunderstandings and issues of compatibility in the area of dispute resolution. ${ }^{16}$ While it is easy to overstate the differences, the more obvious sources of tension included:

- different perceptions of right and wrong between traditional values, mission teaching, and the prescriptions of state law;

- $\quad$ central state control of justice processes and the idea of 'crime' itself, as opposed to the more diffuse quality of customary regulation;

- $\quad$ discrete institutions and professional personnel vested with authority to enforce and administer the law, as opposed to the authority of chiefs, elders and 'big-men';

- a narrow focus on individual responsibility, as opposed to the significance of relationships and the broader context of wrongdoing in customary proceedings;

- $\quad$ reliance on the imprisonment of individual offenders, as opposed to compensation between parties, as the standard redress for serious wrongdoing;

- $\quad$ neglect of victims or aggrieved parties in Western justice;

- the finality of formal legal adjudications, as opposed to the negotiated and often provisional quality of local resolutions;

- the exclusionary and adversarial character of formal judicial proceedings, as opposed to the more participatory and consensual character of local approaches;

- different perceptions of evidence and proof in the determination of responsibility and culpability;

- the apparent absurdity of the overthrowing of the obvious on a technicality in Western justice.

Dissatisfaction with the processes and outcomes of Western justice led to the revival of older forms of self-help in some areas. For example, so-called tribal fighting that had been suppressed temporarily by kiap justice re-emerged in parts of the PNG Highlands in the years immediately preceding independence. ${ }^{17}$ This was, in part, a response to the perceived 
inadequacies of state justice administered by the courts and, in particular, its apparent inability to address the underlying causes of inter-group conflict.

The architects of the independence constitutions sought to accommodate, as far as possible, the existence of both state and customary authority. Kastom and tradition were prominent constructs in the rhetoric of decolonization, providing important markers of national identity in the discourse of early nationalist leaders. ${ }^{18}$ The aspiration to build on the rich legacy of social and legal pluralism was reflected in the constitutions of most newlyindependent Pacific Island countries. It was envisaged that kastom or customary law would play a significant role in the post-colonial legal order although exact details as to how this was to be achieved remained elusive. In Fiji, Papua New Guinea, and the Solomon Islands, kastom was not only recognised as a source of law but was also accorded a high ranking in the constitutional hierarchy of national laws. Vanuatu's Constitution also recognised kastom as a source of law, while the customary authority of chiefs was acknowledged in the Constitutions of both Fiji and Vanuatu.

The goal of building on indigenous social foundations was most explicit in the constitutional vision of Papua New Guinea, the largest and most diverse of the Melanesian countries. While the courts were urged to forge an 'indigenous jurisprudence' (S.21 of the Constitution), ${ }^{19}$ the National Goals and Directive Principles of the Constitution expressly called for 'development to take place through the use of Papua New Guinean forms of social and political organisation' (S.1(6) of the Constitution). They also recognised the importance of community structures, calling for traditional villages and communities to remain as viable units of Papua New Guinea society, and for active steps to be taken to improve their cultural, social, economic and ethical quality' (S.5(4) of the Constitution). The constitutional scheme was thus receptive to the development of a more holistic and restorative approach to crime control and conflict resolution including a greater degree of community participation. A 1977 Law Reform Commission report argued that the formal justice system should take more account of the role of community mechanisms and expectations for dealing with crime and conflict: 
[T] he enforcement of the law has always been a matter for restoring harmony within the aggrieved community. We think that it is right that our courts should be able to take cognisance of the role of the community in the criminal law. ${ }^{20}$

In addition to provisions that sought to encourage the consideration of kastom in formal legal proceedings, a number of Pacific Island countries established courts or tribunals that were designed specifically to deal with local disputes and be responsive and accessible to predominantly rural village communities. The latter were often empowered to apply kastom subject to qualifications. In the Solomon Islands, for example, Local Courts comprising members appointed from the designated court area were established to deal with a range of disputes arising at the local level. ${ }^{21}$ These included offences provided for by legislation, local by-laws and, in certain circumstances, kastom. Local Courts were also given unlimited jurisdiction in customary land matters subject to appeals to Customary Land Appeals Courts.

Vanuatu established Island Courts consisting of three or more justices knowledgeable in kastom, at least one of whom was to be a kastom chief residing in the court area. ${ }^{22}$ Lawyers are excluded from proceedings. Island Courts administer kastom prevailing in their area so far as it is not in conflict with any written law or contrary to justice, morality and good order. Despite calls for their reinstatement, the Fijian Courts that applied kastom to local disputes during the colonial administration were abolished in the lead-up to independence. $^{23}$ Shortly after independence in 1975, Papua New Guinea established a system of Village Courts. The primary role of these courts is to 'ensure peace and harmony' and endeavour to obtain 'amicable settlement of disputes' and apply custom 'as determined in accordance with the Native Customs (Recognition) Act of 1963' (Village Courts Act). They are presided over by village leaders appointed as Village Court magistrates. Under the enabling legislation, the Court should attempt to reach a settlement through mediation prior to exercising its formal jurisdiction. Magistrates can impose fines, issue community work orders, or order that compensation be paid to 
an aggrieved party. While designed primarily for rural areas, these courts now also operate in most urban centres.

Alongside the courts and tribunals of varying degrees of formalism established by the state, numerous unofficial forums for dealing with local disputes with little or no formal connections to state institutions continue to exist. These have not been supplanted by the gradual expansion of the state's regulatory system and they remain an important source of continuity linking the present to the colonial and pre-colonial pasts. Chiefs, elders and other local authority structures, such as komitis, also play a significant role in the settlement of disputes and maintenance of order in most rural communities. While the state constitutes a remote presence in the lives of many rural inhabitants, the Churches provide the most tangible manifestation of a national civil society at local levels and play a significant role in the mediation of local disputes in many areas. For villagers living far from the urban centres, encounters with state law often take the form of heavy-handed police operations or occasional exposure to the complexities of formal justice processes. These experiences reinforce perceptions of difference and incompatibility between local and state processes of social control rather than promoting the complementarity envisaged by the constitutional fathers.

The effectiveness of informal processes of dispute resolution and social control depends on the degree of social cohesion of local communities. Rapid change has had a seriously corrosive impact in many places. This is most apparent in the vicinity of large-scale extractive or commercial projects, along major highways, and in the urban and peri-urban areas. Declining levels of respect for village leaders and customary authority are evident, particularly among youngsters exposed to the urban oriented education system and the hedonistic values of global culture. Likewise, alcohol and other forms of substance abuse have weakened social cohesion in both rural and urban communities, as well as becoming a major source of violence against women and children.

The reach of state justice in the Melanesian countries has been constrained by the challenges of geography, lack of resources, and the escalating and diverse demands placed upon 
law and justice agencies. Disappointing economic performance has limited the capacity of governments to strengthen and extend their law and justice systems in line with population expansion and other developments. Given the low base from which they started, this has had a major impact on their effectiveness. For example, at the time of PNG's independence in 1975, the coverage provided by the 'national' police force extended to only 10 per cent of the total land area and 40 per cent of the population. ${ }^{24}$ The force of approximately 5000 officers has not grown significantly since independence despite the population having more than doubled to 4.6 million people in the intervening years. While successive governments have promised to spend more on policing in the face of growing law and order problems, the necessary funds have not been forthcoming. As well as hampering operational capacity, this has contributed to low morale and serious lapses of discipline among police personnel. The courts have tended to fare better, particularly at the higher levels of the hierarchy where sensitivities about protecting judicial independence are most apparent. Shortage of resources has nevertheless affected the performance of lower courts that deal with the majority of cases involving ordinary citizens.

Papua New Guinea's Village Courts provide a good illustration of both the advantages and the limitations of attempts to institutionalise informal approaches to dispute resolution. Viewed by some as a relatively cheap and accessible alternative to the more formal court system, there are now 1,082 Village Courts covering approximately 84 per cent of the country. ${ }^{25}$ They are by far the busiest courts in the sheer volume of cases dealt with and remain the most accessible forum for dealing with minor disputes. Some observers have complained about the formalism of Village Court proceedings. ${ }^{26}$ Others point out that this formalism is more a reflection of local expectations than a deliberate ploy by magistrates to slavishly imitate the national court system. ${ }^{27}$ Given that Village Courts usually operate alongside a number of unofficial community-based forums, many villagers expect them to be more formal in character.

The operation of these courts varies significantly between different parts of the country. This variation is, in part, 
evidence of how well these courts have adapted to local circumstances as intended originally. At the same time, adaptability can also become a source of injustice. For example, there have been many complaints of Village Courts using kastom to discriminate against women and children, particularly in parts of the Highlands. ${ }^{28}$ Women accused of adultery have been imprisoned while their male accomplices have gone unpunished. Likewise, children have reportedly been locked up for minor offences. These abuses have attracted considerable criticism, not least from women's groups and human rights advocates. In this situation, Village Courts have become overly responsive to local power structures that are almost invariably dominated by older men. In the process, they have served to compound the grievances of the least powerful groups in the community, notably women and children. Such decisions are not only inequitable and discriminatory, they are also in breach of state law. They often involve Village Court magistrates exceeding their jurisdictional powers under the Village Courts Act, and they are also likely to be contrary to human rights provisions under the Constitution.

However, the solution to this problem is not simply to abandon the Village Courts as an institution that inevitably promulgates divisions and inequities rooted in traditional or customary beliefs. This would be to ignore the significant contribution made by these courts to the maintenance of order at local levels. The legislation establishing Village Courts views them as part of a larger national system and provides for the review of their decisions and supervision by District Court magistrates. In practice, lack of resources and inadequate systems of supervision have contributed to these problems. Confusion as to which level of government is responsible for funding Village Courts under the Organic Law on Provincial and Local Level Government has aggravated these problems. In some Village Court areas, magistrates are charging litigants upfront fees for dealing with their disputes on the grounds that they have not received their government allowances, in some cases for several months. In 1999, 130 District Court magistrates were expected to supervise the work of 1,082 Village Courts. ${ }^{29}$ This is quite unrealistic, particularly given the inaccessibility of many 
rural Village Courts and other constraints on District Court magistrates. The remedy for these deficiencies of the Village Courts lies in strengthening their linkages to the formal court system, principally through the provision of adequate and practical processes of review and supervision.

Capitalist development in the Pacific Islands, as elsewhere, has been accompanied by growing disparities of wealth and power within and between countries, as well as between individuals and groups. High rates of population growth, low levels of economic growth, mismanagement and corruption, incapacitated government services, pressures on land, internal migration, urbanisation, and a highly uneven pattern of development, have all contributed to new forms of tension and conflict. These have been most apparent in Papua New Guinea, which has acquired an unenviable reputation for the scale and intractability of its 'law and order' problems. ${ }^{30}$ While these are by no means as uniform as implied in media accounts, they have generated widespread insecurity and constitute a major disincentive to tourism and other forms of foreign investment. The larger urban centres have become notorious for their high rates of violent crime, attributed to raskol gangs. Sexual assaults against women are alarmingly high. Police responses have had relatively little impact in countering these trends and, in many cases, have made matters worse through the use of excessive and indiscriminate force. Lengthy delays in court hearings and regular prison breakouts support the impression of a law and justice system that is being increasingly overwhelmed by the demands placed upon it. Criminal violence has also spread to many rural areas. Inter-group fighting has increased in parts of the Highlands and become ever more deadly through the use of high-powered firearms. Raskolism, banditry, and inter-group fighting have come together in some places, such as the Southern Highlands. This has resulted in fighting of such intensity that the state has been forced to abandon essential services such as education and health. In these circumstances, the state cannot carry out its most basic function - administering justice and ensuring security.

While the size and relative wealth of Papua New Guinea contribute to the scale of its problems, many of the same underlying factors and dynamics are evident in the other 
Melanesian countries. The groups of frustrated young men and boys hanging around the streets of Suva, Honiara, and Port Vila are the same constituency that gave rise to raskolism in Port Moresby and other PNG towns. Warnings are issued regularly that Suva, Honiara, Port Vila and other Pacific Islands towns are going the way of Port Moresby. According to the Prime Minister of Vanuatu, Edward Natapei, 'urban areas cannot provide adequate employment opportunities for these young people who may become frustrated and ultimately resort to anti-social behaviour as has occurred in some of our neighbours' (Port Vila Presse 18 August 2001). Youngsters brought up in urban settlements, or who have arrived from distant rural villages, congregate in town centres in search of excitement and employment. The challenges of identity, survival and livelihood facing these young people are broadly similar throughout the Pacific islands. In Honiara, they form a distinct youth subculture, known locally as Master Liu. ${ }^{31}$ Like their counterparts in Port Vila, referred to as Sperim Publik Rot (SPRs - 'spare on the side of the road' or 'hanging out') (Vanuatu Yang Pipol's Projek 1999), or Suva, ${ }^{32}$ these groups of unemployed or under-employed youth verge on delinquency. Official responses to this expanding and highly visible constituency have often consisted of representing it as a 'youth problem' and applying 'law and order' solutions, mainly in the form of reactive policing. Violent encounters between police and youth have become commonplace in many of the larger urban centres. In practice, these often serve simply to aggravate underlying grievances and reinforce criminal or deviant identities.

Dissatisfaction with the workings of formal criminal justice systems has grown as their deficiencies have become more apparent. It is clear that many ordinary citizens have little faith in either the efficiency or fairness of formal justice. There is a popular perception of a widening gap between 'law' and 'justice' in many places and a view that those with power and influence can manipulate the formal system to their own advantage. In this respect, the deficiencies of the state system relate as much to its lack of legitimacy, as to its lack of institutional capacity. In Vanuatu, Mitchell has written about local perceptions of the limitations of 'white man's' justice and 
the superiority of kastom in the context of a homicide trial in Port Vila. ${ }^{33}$ This is particularly evident among young people who are the main target of 'law and order' responses. The following recommendation appeared among resolutions of a recent National Summit on Juvenile Justice in Port Vila:

1. Young people of Vanuatu want custom laws and custom courts to deal with them when they commit offences. This is because:

(i) they are mistreated by the police when taken into their custody;

(ii) the state law court process is too expensive and takes too long;

(iii) young people are not stigmatised by going through the custom court process, and have the opportunity to redeem their reputation;

(iv) young people know their chief and the other members of their community who witness the custom court, and are therefore not intimidated to the degree that they are by state courts;

(v) only custom law can fix problems and restore peace to communities' 34

The fragility of formal law and justice institutions and processes in parts of the Pacific Islands is undeniable and has been demonstrated most dramatically in the calamitous collapse of the Solomon Islands police during the recent conflict in that country. As a significant regional donor, Australia has been involved in major capacity-building projects with the law and justice sector in PNG for many years and has extended this work to other Pacific Islands countries. While this assistance is critical and necessary, it is equally important to strengthen those informal mechanisms and institutions that are capable of dealing with minor infractions and conflict at community levels. Empowering communities to take responsibility for maintaining peace at local levels will enable the formal sector to concentrate on more serious matters. Building appropriate linkages between formal and informal sectors will help build the social foundations and legitimacy whose absence is a significant contributor to the weakness of the former. This is not simply a 
question of returning to some idealised vision of customary regulation but entails a careful approach to building the capacity of the informal sector in a way that is consistent with the rule of law and respect for human rights.

\section{What the Chapters say}

John Braithwaite, a leading theoretician of the restorative justice movement, ${ }^{35}$ sets the conceptual stage with his lucid summary of the fundamental features of restorative justice. He presents both a process and a values conception of the term. In the former, restorative justice comprises a process where all the stakeholders affected by a particular injustice have an opportunity to discuss the consequences of what might be done to put them right. In the latter, restorative justice is about responding to injustice with healing as opposed to the infliction of further pain. According to Braithwaite, the key value of restorative justice is non-domination and the active part of this value is the empowerment of the main stakeholders in a particular injustice. He opts for a minimalist definition of the prescriptive normative content of restorative justice, confining it to non-domination, empowerment and what he calls 'respectful listening'. Each stakeholder should be provided with an opportunity to narrate their stories of how they have been affected and how the injustice can be put to right. The emphasis on empowerment means that stakeholders are free to choose a retributive outcome in a particular case provided, of course, that such an outcome does not entail any breach of the fundamental rights of the wrongdoer. This minimalist conception allows for the development of a rich repertoire of restorative justice practices consistent with different cultural contexts. For Braithwaite, it is not a case of either restorative justice or formal justice. There may be circumstances where formal justice is more empowering for particular groups of stakeholder, such as women, while in other contexts the opposite may be true. In many cases, a combination of formal and restorative justice may provide the most just and empowering resolution.

Several contributors raise concerns about the concept and practice of restorative justice. In his chapter about the 
challenges of social control in a rapidly changing urban village in Port Moresby, Michael Goddard sets out to show that restorative justice cannot be analytically abstracted from its immediate social context and that it can come unstuck on the contestability of the cultural meaning to which it is putatively adapted in that context. He tells the story of how restorative strategies have become institutionalised in the workings of the Pari village court and how they draw on the community's powerful sense of Christian and traditional identity. While these strategies were successful in the past, they have encountered growing resistance among contemporary male youth whose identities and behaviour have been affected significantly by the harsh socio-economic realities of the adjacent and culturally heterogenous city. For Goddard, the critical issue in this changing environment is the capacity of restorative institutions to adapt in culturally meaningful ways.

Alan Rumsey takes issue with what he sees as a core value underlying debate on restorative justice, namely the notion that people everywhere seek to achieve and preserve community as a valued state of affairs and that conflict is seen as a threat to that valued state of affairs. Drawing on his ethnographic work in the Western Highlands of Papua New Guinea, he argues that warfare and peacemaking are integral aspects of a single exchange system. Rumsey narrates the remarkable story of the Kulka women's group and their successful intervention to end a longstanding tribal conflict. Rather than being about the restoration of a previous state of affairs that had been disrupted by warfare, Rumsey argues that the intervention was successful because it transformed that earlier state of affairs. Echoing a more general criticism of the concept of restorative justice, Rumsey advocates a transformative justice capable of redressing injustices arising from underlying inequalities, as opposed to an inherently conservative restorative justice aimed at restoring the status quo.

Aspects of Rumsey's critique are taken up in a number of other contributions. Reflecting previous criticisms of customary forms of dispute resolution, ${ }^{36}$ Rita Naviti outlines the dangers of literal forms of restorative justice in societies where men are dominant and women occupy a subordinate role. She points to 
the underlying injustices arising from women's customary status in Vanuatu and the continuing practice of bride price. Applying kastom as a form of restorative justice under such circumstances risks reinforcing underlying gender inequities and may ultimately be conducive to perpetuating injustice. While recognising the attractions of restorative strategies in relation to particular forms of infraction, as in the case of juvenile offenders, she suggests that in other instances what is required is a combination of customary and formal justice. Jolly makes a similar point, arguing for a more transformative process of justice capable of proactively creating peace and harmony in a way that is fair to all members of the community concerned.

While one might have anticipated a degree of resistance to the ideas of restorative justice from practitioners steeped in the traditions of the formal justice sector, two of Vanuatu's most senior law officers expressed strong support for the concept and its practical development. The then Police Commissioner, Peter Bong, points to the strength of kastom law and the continuing role of chiefs as arbiters of disputes in Vanuatu. He also emphasises the limited sense of ownership of Western laws that have been adopted from colonial times. For Commissioner Bong, community policing offers strong restorative prospects and should involve close consultation with chiefs and community leaders and the encouragement of informal settlements of minor disputes. Among other things, such an approach provides an important way of overcoming a long history of poor police/community relations. The Honourable Justice Vincent Lunabek speaks about Alternative Dispute Resolution (ADR) in the civil justice system and its similarity to traditional forms of dispute resolution. He calls for an extension of the ADR system and points to its restorative potential for repairing relationships damaged by dispute. Such an approach is highly desirable, particularly in the Melanesian social environment where people remain connected and dependent on each other.

John Ivoro tells the story of a dispute settlement committee established in an urban settlement in Port Moresby, Papua New Guinea. Ethnic tensions and violence, often associated with alcohol abuse, have plagued the settlement. A number of community leaders undertook conflict resolution 
training with the Peace Foundation Melanesia, a Port Moresby based non-government organisation. These skills were then adapted to the particular circumstances of the settlement. The dispute settlement committee has conducted over 200 mediations within a three-year period using restorative techniques. Good working relations have been forged with the local village court, other government agencies, churches, NGOs and the private sector. The resolutions of the committee attempt, wherever possible, to address the underlying causes of conflict and anti-social behaviour. Ivoro's story provides a good illustration of how restorative strategies can be successfully adapted to the challenges of ethnically mixed urban communities. Ruby Zarriga, a senior planner with the PNG government, discusses the linkage between restorative justice and community strengthening. The emphasis on community participation in the former can contribute to a broader process of empowerment that encourages local communities to take more responsibility for their own well-being and development. Restorative justice has the potential for working with, and through, the relationships and social networks that are such an important feature of Melanesian communities.

Peni Moore describes the innovative work of a nongovernment organisation, Women's Action for Change (WAC), in the Fiji prison system. It is the story of a successful partnership between an NGO and a state agency and shows that restorative strategies can have an impact even inside explicitly retributive institutions. As in most prisons in the region, resources for rehabilitation programs in Fiji are extremely limited. Former prisoners experience considerable difficulties on their release and often end up in prison again. In collaboration with the Fijian prison authorities, WAC has been using 'playback' theatre, exercises and games aimed at improving the communications skills and self-esteem of young inmates and, thereby, their chances of successful re-entry into society after discharge. Much of this work has involved challenging ingrained attitudes towards gender, identity and violence and the evidence presented suggests a considerable level of success.

Joemela Simeon and Paul Vuhu provide further illustrations of restorative practices in contemporary Vanuatu. 
While still at its inception stage at the time of the conference, Simon discusses the background to the proposed juvenile justice project based at the Vanuatu Cultural Centre. He points to the widespread lack of familiarity with Western law and process and the strong preference expressed by young people to have their disputes and infractions dealt with under kastom rather than by the police and courts. While noting the particular challenges of using kastom in the pluralistic urban context, he echoes Commissioner Bong in his call for closer consultation between kastom leaders and representatives of the formal legal system. Vuhu describes the work of the Lakalakabulu Area Council of Chiefs (LACC) and their role in dispute settlement. He speaks of a familiar restorative process involving participation, lengthy deliberations and consensual decision-making. According to Vuhu, the LACC works closely with local police, provincial authorities, churches, village councils of chiefs and other nongovernment organisations. In addition to resolving disputes in a way that is familiar and acceptable to rural villagers, he stresses the accessibility of this approach as opposed to that provided by the formal justice system.

Whereas the discussion of restorative prospects in Vanuatu took place against the backdrop of a relatively peaceful environment, other speakers came from places beset by political instability, ethnic tensions, and, in some cases, inter-communal violence. With George Speight and his associates still in control of Fiji's parliamentary complex, Steven Ratuva discusses the vexed issue of ethnic relations in his country and the potential role of informal justice strategies in promoting reconciliation. He observes how the requirements of formal legal justice and intercommunal reconciliation appear to be increasingly at odds in the context of recent political developments. Creating the appropriate conditions for peacebuilding between indigenous Fijian and Indo-Fijian communities is an important priority. To this end, Ratuva introduces the Fijian practice of veisorosorovi as a possible model that could be adapted for this purpose. Veisorosorovi helped promote social stability and peace in indigenous Fijian communities by reconciling parties to conflict and is a process with distinctly restorative characteristics. It is conducted through a formal ceremony and involves reciprocal 
presentations between the parties using traditional items such as tabua (whale's tooth) and yaqona (kava). Admissions of mistakes on the part of the wrongdoer are followed by requests for forgiveness. It is a ceremonial process involving the kin groups of both parties and is aimed at reconciling differences between these larger communal entities. Ratuva goes on to suggest ways in which this model might be adapted to suit the circumstances of Fiji's current situation and how it might contribute to rebuilding trust and confidence between ethnic Fijian and IndoFijian communities.

Alumita Durutalo pursues a similar line of enquiry in her examination of traditional and introduced modalities of conflict resolution in Fiji. In the former context, she claims that the primary purpose of punishment was not to alienate but to reform. The absence of any significant reform dimension in the practice of modern judicial punishment is, in her view, a contributing factor to the current high rates of recidivism in Fiji (see Moore this volume). She also makes the connection between the marginalisation of large numbers of Fijian youth and increasing levels of social and political instability. Many Fijian youth are now caught in a vicious cycle of marginalisation, criminality and incarceration that is reinforced by the operations of the formal justice system. For Durutalo, the way forward is neither a singular reliance on formal or informal justice but a selective and creative integration of both.

The dangers of simplistic appeals to customary justice are amply documented in Father Norman Arkwright's account of the corruption of 'traditional' compensation in the Solomon Islands. As in many other parts of Melanesia, the institution of compensation has a long history in the Solomon Islands as a means of settling disputes and redressing grievances within and between groups. In the kastom context it involved a complex process of negotiation and exchange and, in practice, was subject to numerous constraints. Over the years it has been extended to a variety of non-traditional situations, including claims against the state. ${ }^{37}$ Political leaders have been particularly receptive to claims based in appeals to kastom and compensation claims against the government have increased accordingly. ${ }^{38}$ While compensation has moved beyond the 
restraints of kastom, state law has made little attempt to regulate what is presented as a 'traditional' practice. Compensation has also become increasingly commercialised, with monetary payments replacing traditional items of wealth. This has opened up new opportunities for self-enrichment. The sheer number of potential claimants in the conflict on Guadalcanal magnified the potential for abuse. Demands are often accompanied by threats and intimidation and its uneven distribution has generated further feelings of grievance and injustice. In short, the corruption of the compensation process, as underwritten by the national government, has itself become a significant contributor to the continuing disorder in the Solomon Islands. ${ }^{39}$ In Arkwright's view, there is a need to assert Christian forms of redress as the real way to restore broken relationships in the Solomon Islands. These can set the tone for genuine reconciliation between the people of Guadalcanal and Malaitan communities and can be aligned in a more constructive way with aspects of customary justice. Arkwright's reminder of the centrality of Christian beliefs in the daily lives of Solomon islanders is salutary and helps explain another important source of the appeal of restorative justice in the Pacific islands. Restorative strategies resonate with elements of both traditional and Christian values, two major sources of contemporary Melanesian morality. The convergence between these belief systems and restorative justice is evident in many of the other contributions and notably those from post-conflict Bougainville.

While older methods of managing conflict are invariably adapted to changing circumstances, it is by no means inevitable that they become corrupted along the lines outlined by Arkwright. Just as larger conflicts can undermine the effectiveness and integrity of both 'traditional' and 'modern' forms of conflict resolution, they may also serve as catalysts for the emergence of new approaches that synthesise elements of old and new. The Bougainville peace process provides many examples of this phenomenon and there is much to be learnt from these experiences by others in the region and beyond. ${ }^{40}$ Ruth SaovanaSpriggs discusses the way in which Bougainvillean women built on their traditional role as peacemakers in bringing together and helping reconcile formerly opposing groups. She points to the 
need for flexibility in the design and application of restorative techniques in order to accommodate the high degree of social diversity on Bougainville. Her story of a women's association mediating between two armed groups in the Buin district is one of courage, tact and perseverance. She illustrates the critical, often discrete, role of Bougainvillean women in helping create the conditions necessary for proceeding onto the more formal negotiations in New Zealand that eventually led to the current peace agreement.

Brother Pat Howley recounts his experiences as a trainer with the Peace Foundation Melanesia on Buka and mainland Bougainville. The Foundation has been active in providing training in conflict resolution to community leaders and others in many different parts of Papua New Guinea. On Bougainville, the work of the Foundation occurred in an environment traumatised by violent conflict within and between communities and one where the formal justice system had largely collapsed because of the war. Considerable hostility towards anything associated with 'the government' existed in many places, particularly in areas controlled by the Bougainville Revolutionary Army (BRA). The early work of the Foundation in the mid-1990s was taken up enthusiastically by local leaders and resulted in many successful mediations and reconciliations between individuals and groups. There were also enormous risks involved in such a situation and, tragically, three trainers were killed when violence broke out again between the various factions. The ending of the fighting in 1997 was marked by renewed engagement by Foundation trainers with the active support and participation of local chiefs, women's groups, churches, and leaders of the militant factions. Mediation and restorative strategies have been used successfully for even the most serious acts of violence. According to Howley, the development of restorative techniques, consistent with older Bougainvillean forms of dispute resolution, have served to dispel much of the fear and distrust of justice processes that prevailed previously in many parts of the island. He echoes the point made by Zarriga (this volume), that restorative justice has considerable potential for empowering communities and re-building social cohesion. 
John Tombot provides a poignant account of the human dimensions of the conflict in the Siwai district of south-west Bougainville and the challenges of post-conflict reconciliation and healing. Local communities have been divided and deeply traumatised by nine years of fighting. Tombot is a traditional chief and former village court magistrate, and is an enthusiastic proponent of restorative mediation as a way of re-building trust and peace within and between local communities. He has been involved in the facilitation of over 300 mediations in the Korikuna area of Siwai. These entail high levels of participation, prolonged deliberation, and appeals to Christian values, and are concluded with moving acts of reconciliation. In his view, these forms of mediation are likely to be successful because they accord closely with local perceptions of how justice should be done. Formal justice, on the other hand, failed to appeal because it excluded ordinary people from participation. It also created further divisions through its adversarial character. Taking disputes to court became a way of making money (through compensation claims) for many parties and led to further disagreements and conflict (see Arkwright this volume). Tombot's vision of an integrated approach that combines elements of indigenous and introduced forms of justice appears to be shared by the architects of the future system of governance being devised for the newly autonomous Bougainville. ${ }^{41}$

Margaret Jolly's chapter points out that the challenges to peace in the region go well beyond the immediate manifestations of conflict and disorder. They also reflect complex divisions around the changing hierarchies of rank, seniority and gender; the inequalities arising from capitalist developments; new forms of education; and the structures of the nation-state in a rapidly globalising world. There is a necessary but challenging relation between justice in the broader political sense of redressing underlying inequalities and justice in the narrower legal sense of adjudicating conflicts fairly in the pursuit of harmonious outcomes. Given the different traditions of justice and the divergent interests of men and women, the best prospects lie not so much in a recuperation of pre-colonial forms of conflict resolution but in the development of a transformative justice that is capable of overcoming the inequities and 
deficiencies of both indigenous and introduced systems and that can connect creatively between them.

\section{Conclusions}

The optimistic accounts provided by many of the speakers in Vanuatu are a welcome change from the gloom and despair that pervades so many commentaries about the contemporary Pacific. This optimism, of course, does not detract from the formidable challenges in the region. There is no single, quick or straightforward solution. For many Western-trained economists and technocrats, the resilient 'cultures' of Melanesia are often viewed as a major source of the inefficiencies and incapacity of state structures and a hindrance to 'rational' processes of economic accumulation and growth. A powerful counter message from the conference - and this book - is how these very same 'cultures' can be an important part of the solution to current problems. Much of the optimism is based on the resonance between restorative processes and indigenous traditions of dispute resolution, peacemaking and reconciliation. The implicit proposition is that approaches to conflict that work with and through local cultural beliefs and practices hold out greater prospect of success than those that work against them. This is not a case of returning to some idealised world governed by pre-colonial kastom, even were that possible. Kastom can be oppressive and discriminatory, just as it can be respectful and empowering. For most of our contributors, the way forward is neither a singular reliance on kastom or Western justice but a creative integration of the best of both.

While drawing attention to the limitations of narrow state-centred approaches in the Melanesian context, developing restorative approaches should not be seen simply as an alternative to building the capacity of state institutions. On the contrary, the promotion of restorative strategies can be an important way of enhancing the effectiveness of the latter. Lack of state capacity is often viewed as a 'technical' problem to be remedied by strategic inputs targeted exclusively at state institutions. The question of a state's relations to its wider society and the extent to which these might themselves be a source of its 
limited capacity is rarely raised. At the same time, it is clear that a large part of the weakness of state institutions in the Melanesian countries, including the formal justice system, is as much a consequence of their limited legitimacy, as it is a shortage of resources, 'technical' or otherwise. Strengthening the capacity of the formal justice system requires that priority be given to improving relations with the wider society it exists to serve. Community participation in justice processes, as entailed in restorative approaches, is a necessary part of building the social foundations whose absence is a significant contributor to the current weakness of state processes. Another attraction of restorative initiatives is the prospect they hold out of more direct engagement with the underlying causes of conflict, including the structural conditions that contribute to crime (e.g. by providing pathways back to legitimate economic activities). An important source of the weakness of formal justice lies in its inability to address broader issues of social justice. Indeed, many local critics view the formal system as reinforcing underlying injustices. The potential to engage with social justice issues provides another way of building the legitimacy and effectiveness of justice and conflict resolution practices.

\section{Acknowledgement}

I would like to thank Hank Nelson for his helpful comments on an earlier version of this chapter. 


\section{Endnotes}

1 Dinnen, Sinclair and Allison Ley (eds) 2000. Reflections on Violence in Melanesia

2 Dinnen, Sinclair 2001a. 'Restorative Justice and Civil Society in Melanesia: The Case of Papua New Guinea'.

3 Regan, Anthony J 2000 "'Traditional" Leaders and Conflict Resolution in Bougainville: Reforming the Present by Re-writing the Past?'; Howley, Pat 2002. Breaking Spears \& Mending Hearts

4 Braithwaite, John and Heather Strang 2001. 'Introduction: Restorative Justice and Civil Society': p 1

5 Held, David et al (eds) 1983. States and Societies: p 6

6 Weber, Max 1972. 'Politics as a Vocation'

7 Cohen, Youssef et al 1981. 'The paradoxical nature of state making: the violent creation of order'

8 Singer, P W 2001/2002. 'Corporate warriors: the rise of the privatised military industry and its ramifications for international security'

9 Herbst, Jeffrey 2000. States and Power in Africa: Comparative Lessons in Authority and Control

10 Strathern A J and P J Stewart 1997. 'The problems of peace-makers in Papua New Guinea: modalities of negotiation and settlement'

11 Roberts, Simon 1976. 'Law and the study of social control in smallscale societies', p 667

12 Strathern, A J and P J Stewart 1997 op cit: p 698

13 Ibid: $p 685$

14 Gore, Ralph T 1929. 'The Punishment for Crime among Natives'. p 20

15 Dinnen, Sinclair 2001b. Law and Order in a Weak State: Crime and Politics in Papua New Guinea: pp 16-24

16 Powles, Guy 1988. 'Law, Courts and Legal Services in Pacific Societies': pp 8-9

17 Gordon, Robert 1983. 'The decline of the kiapdom and the resurgence of "tribal fighting" in Enga'

18 Narakobi, Bernard M 1983. The Melanesian Way

19 Constitution of the Independent State of Papua New Guinea.

20 Papua New Guinea Law Reform Commission (PNG LRC) 1977. The Role of Customary Law in the Legal System

21 Takoa, T and John Freeman 1988. 'Provincial Courts in the Solomon Islands'

22 Bulu, Hamlison 1988. 'The Judiciary and the Court System in Vanuatu'

23 Nadakuitavuki, Viliame D 1988. 'Fijian Magistrates — An Historical Perspective' 
24 Dorney, Sean 1990. Papua New Guinea: People, Politics and History since 1975: p 296

25 Papua New Guinea Department of Attorney General 1999. Brief to the Minister for Justice, Honourable Kilroy K.Genia, MP: pp 93-94

26 Paliwala, A 1982. 'Law and order in the village: Papua New Guinea's village courts'. In Sumner, C (ed) Crime, Justice and Underdevelopment: pp 192-227

27 Goddard, Michael 2000. 'Three Urban Village Courts in Papua New Guinea: Some Comparative Observations on Dispute Settlement'.

28 Garap, Sarah 2000. 'Struggles of Women and Girls - Simbu Province, Papua New Guinea'

29 Papua New Guinea Department of Attorney General 1999

30 Dinnen, Sinclair 2001b

31 Jourdan, Christine 1995. 'Master Liu'

32 Veramu, Joseph C 1994. Moving Through the Streets

33 Mitchell, Jean 2000. 'Violence as Continuity: Violence as Rupture Narratives from an Urban Settlement in Vanuatu'. pp 201-203

34 Braithwaite, John 1989. Crime, Shame and Reintegration

35 Recommendations of the National Stakeholders Summit on Juvenile Justice, Port Vila, 30th March 2001 — Draft Version.

36 Garap, 2000, Mason, Merrin 2000. 'Domestic Violence in Vanuatu'

37 Akin, David 1999. 'Compensation and the Melanesian state: why the Kwaio keep claiming'

38 Steeves, Jeffrey S. 1996. 'Unbounded politics in the Solomon Islands: leadership and party alignments'

39 Dinnen, Sinclair 2002. 'Winners and losers: politics and disorder in the Solomon Islands'

40 Carl, Andy and Lorraine Garasu 2002. 'Weaving consensus: the Papua New Guinea-Bougainville Peace Process'

41 Regan, 2000 